\title{
ERYTHROCYTE ANTIOXIDATIVE ENZYME ACTIVITIES AND LIPID PEROXIDATION LEVELS IN PATIENTS WITH CUTANEOUS LEISHMANIASIS
}

\author{
KOCYIGIT A.*, GUREL M.** \& ULUKANLIGIL M.***
}

\section{Summary:}

Although cutaneous leishmaniasis $(\mathrm{CL})$ is a local infection, the cellular immune response against the disease is systemic, and reactive oxygen intermediates ( $R O / \mathrm{s}$ ) are an important part of cellular immune response involved in killing the parasite. However, whether these intermediates cause oxidative damage in host is unknown. In this study, the metabolism of $\mathrm{RO}$ ls were investigated in patients with $\mathrm{CL}$, and compared with healthy subjects.

Erythrocyte lipid peroxidation was determined, as an index of oxidative damage, by measurement of malondialdehyde (MDA) levels. Erythrocyte MDA levels and SOD activities were found to be significantly higher in $\mathrm{Cl}$ patients than in control subjects $(p<0.01$ and $p<0.01$, respectively). However, CAT and GSH$P x$ activities were significantly lower in the $C L$ group $\mid p<0.05$ and $p<0.01$, respectively). There was a tendency to decreased hemoglobin $(\mathrm{Hb})$ levels, but values did not reach statistical significance. These findings suggest that changes in antioxidant enzyme activities may amplify the leishmanicidal effect in patients with $\mathrm{Cl}$. However, these changes may not only cause the killing of parasite but also may cause oxidative damage in the other cells or tissues.

KEY WORDS : cutaneous leishmaniasis, lipid peroxidation, antioxidative enzymes.
Résumé : ACTIVITÉ ENZYMATIQUE ANTIOXYDANTE DES ÉRYTHROCYTES ET DEGRÉ DE PEROXYDATION DES LIPIDES DE PATIENTS ATTEINTS DE LEISHMANIOSE CUTANÉE

Bien que la leishmaniose cutanée (LC) soit une infection locale, il existe une réponse immunitaire systémique cellulaire, et des intermédiaires réagissant avec l'oxygène représentent une part importante de cette réponse visant à détruire le parasite. Cependant, la possibilité de lésions oxydatives liées à ces intermédiaires chez l'hôte n'est pas élucidée. Leur métabolisme a été étudié chez des patients atteints de LC et comparé à celui de sujets sains. La peroxydation des lipides des érythrocytes a été déterminée, comme index de lésion oxydative, par la mesure du niveau de malondialdéhyde (MDA). Le niveau de MDA et l'activité superoxyde dismutase erythrocytaire ont été trouvés

significativement plus élevés chez les porteurs de $L$ que chez les sujets témoins ( $p<0,01$ et $p<0,01$, respectivement). Cependant, les activités catalase et glutathion peroxydase sont significativement plus basses dans le groupe $L C$ l $p<0,05$ et $p$ $<0,01$, respectivement). Il y a une tendance (non significative) à la baisse du taux d'hémoglobine. Ces résultats suggèrent que des modifications de l'activité enzymatique antioxydante pourraient amplifier la réponse immunitaire des porteurs de LC contre le parasite. Cependant, ces modifications pourraient également causer des lésions oxydatives chez d'autres cellules et tissus de l'hôte.

MOTS CLÉS : leishmaniose cutanée, peroxydation de lipides, enzyme antioxidant.

The mechanism(s) by which defense cells kill microorganisms has been the subject of intense research. Although, it is now apparent that nitric oxide (NO) has an important role, reactive oxygen intermediates (ROIs) have also an important role in parasite killing (Assruey et al., 1994). Numerous studies have demonstrated that organisms produce ROIs such as hydrogen peroxide $\left(\mathrm{H}_{2} \mathrm{O}_{2}\right)$, superoxide $\left(\mathrm{O}_{2}^{-}\right)$and hydroxyl $(\mathrm{OH})$ radicals as a host defense strategies to kill intracellular and extracellular parasites (Li et al., 1992).

In healthy organisms, there is a delicate balance among oxidants and antioxidants such as superoxide dismutase (SOD), catalase (CAT), glutathion peroxidase (GSH-Px), vitamins E, C and A. Under pathological conditions the balance may be tilted toward oxidative side, with the end result being uncontrolled oxidative damage (Mc Cord, 1993).

Recently, we have demonstrated that antioxidative enzyme activities change in patients with $\mathrm{CL}$, pro- 
bably as host defense (Erel et al., 1999). However, we have not determined whether these changes cause oxidative damage in these patients. In this study, the changes of erythrocyte antioxidant enzyme activities and the levels of lipid peroxidation, as an index of oxidative damage, were evaluated in patients with CL.

\section{MATERIALS AND METHODS}

The study was conducted at Harrankapi Leishmania Treatment Center in Sanliurfa, which is a hyperendemic area for leishmaniasis in southeastern Anatolia in Turkey (Gurel et al., 2002). 32 patients with localized CL, 19 man and 13 women, aged 10 to 34 years $(28.2 \pm 4.3)$ were enrolled in the study. Admission criteria for the patient group were as follows: no pregnancy and no prior intralesional or systemic antimonial therapy or no bacterial infection. All patients had nodular or noduloulcerative leishmanial lesions. Patients with lesions of six months or greater duration were excluded from the study because of the possibility of spontaneous healing and immunity.

The clinical diagnosis was confirmed by laboratory demonstration of the parasite in the lesions by direct smears. Lesions were cleaned with ethanol, and punctured at the margins of the lesions with a sterile lancet. Biopsy material was smeared, dried in air and fixed by methanol. Parasitologic diagnosis was based on visualisation of parasites in Giemsa-stained smears, prepared with material aspirated from borders of skin lesions and from tissue imprints from biopsy. In order confirm the diagnosis, the materials were also cultured Novy-MacNeal-Nicolle (NNN) medium for up to three weeks to detect leishmanial promastigotes. The parasites were classified by izoenzyme analyses by using starch gel electrophoresis techniques (Gramicia et al., 1984). In all cases the strains corresponded to the Leishmania tropica.

A total of 30 healthy volunteers, 17 man and 13 women, aged 11 to 33 years $(27.3 \pm 4.5$ years), served as controls from in the same area. None had received any systemic disease and none had received either mineral or vitamin drugs.

\section{SAMPLE PREPARATION}

In total, $10 \mathrm{ml}$ of heparinized venous blood was drawn after overnight fasting and mixed with $10 \mathrm{ml}$ of Dextran $\mathrm{T} 5006 \% \mathrm{w} / \mathrm{v}$ in saline $0.9 \% \mathrm{w} / \mathrm{v}$ in a $25 \mathrm{ml}$ tube and kept at room temperature for $30 \mathrm{~min}$ before the leukocyte-rich plasma layer was removed. After the leukocyterich plasma was discharged, the remaining erythrocytes were washed repeatedly with an isotonic solution of $\mathrm{NaCl}$ $(0.9 \%)$ until a colorless supernatant was observed. Erythrocyte membrane malondialdehyde (MDA) levels were measured, as a marker of lipid peroxidation, in $100 \mu \mathrm{l}$ of packed erythrocytes. $500 \mu \mathrm{l}$ of packed erythrocytes were destroyed by the addition of four volumes of cold redistilled water in order to measure antioxidative enzyme, SOD, GSH-Px and CAT activities. Suspension was centrifuged twice to obtain erythrocyte membranes and hemolysate: first for $10 \mathrm{~min}$ in a tube centrifuge at $1,500 \times \mathrm{g}$ at $4^{\circ} \mathrm{C}$, and then in an eppendorf centrifuge at $5,000 \times \mathrm{g}$ for five min at $4^{\circ} \mathrm{C}$. Clear supernatant was obtained as hemolysate. Remaining erythrocyte membrane was used to measure MDA contend. Blood hemoglobin $(\mathrm{Hb})$ levels and, erythrocyte counts were measured by automatic blood analyzer (Coulter, Stakes, USA) and hemolysate hemoglobin ( $\mathrm{Hb}$ ) levels were measured by the cyanmethemoglobin method (Von Kompen \& Zililstra, 1961). All enzyme activities were measured from the hemolysate. Hemolysate antioxidant SOD and GSH-Px enzyme activities were measured with commercially available kits (Randox, Lab. Ltd. Ireland Cat. No. SDI 25 and RS505 respectively).

\section{DETERMINATION OF ERYTHROCYTE SUPEROXYDE DISMUTASE ACTIVITY}

Erythrocyte SOD activity was determined with a Randox test combination. Xanthine and xanthine oxidase were used to generate superoxide radicals reacting with 2-(4iodophenyl) 3-(4-nitrophenol) - 5-phenyl tetrazolium chloride (INT) to form a red formazan dye (McCord \& Fridovich, 1969). Superoxide dismutase inhibits this reaction by converting the superoxide radical to oxygen. Superoxide dismutase activity was measured at $505 \mathrm{~nm}$ on a cessil 3000 spectrometer in hemolysates of washed erythrocytes. Results were expressed in SOD U/g Hb.

\section{DETERMINATION OF ERYTHROCYTE GLUTATHION PEROXIDASE ACTIVITY}

Measurement of GSH-Px activity was based on the following principle: GSH-Px catalyses the oxidation of glutathione by cumene hydroperoxide (Paglia \& Valentine, 1967). In the presence of glutathione reductase and nicotinamide adenine dinucleotide phosphate (NADPH) the oxidized glutathione is immediately converted to the reduced form with a concomitant oxidation of NADPH to NADP+. The decrease in absorbance at $340 \mathrm{~nm}$ is measured. Erythrocyte GSH-Px activity was expressed as U/g $\mathrm{Hb}$. The enzyme unit of GSH-Px (U) is defined as the number of mmoles of reduced NADPH oxidized per minute at $37^{\circ} \mathrm{C}$ by $1 \mathrm{~g}$ of $\mathrm{Hb}$ under standard assay conditions. Measurements were performed by automatic analyzer (Hitachi 911, Boehringer Mannheim, Germany) according to the Randox application procedure.

\section{DETERMINATION OF ERYTHROCYTE CATALASE ACTIVITY}

CAT activity in erythrocyte was assayed by a method described by Goth (Goth, 1991). Of the hemolysate 
$0.2 \mathrm{ml}$ erythrocyte hemolysate was incubated in $1.0 \mathrm{ml}$ substrate $\left(65 \mathrm{mmol}\right.$ per $\mathrm{H}_{2} \mathrm{O}_{2}$ in $60 \mathrm{mmol} / \mathrm{L}$ sodiumpotassium phosphate buffer, $\mathrm{pH} 7.4$ ) at $37^{\circ} \mathrm{C}$ for $60 \mathrm{~s}$. The enzymatic reaction was stopped with $1.0 \mathrm{ml}$ of $32.4 \mathrm{mmol} / 1$ ammonium molybdate $\left(\left(\mathrm{NH}_{4}\right)_{6}\right.$ $\mathrm{MO}_{7} \mathrm{O}_{24} \cdot 4 \mathrm{H}_{2} \mathrm{O}$ ) and the yellow complex of molybdate and $\mathrm{H}_{2} \mathrm{O}_{2}$ was measured at $405 \mathrm{~nm}$ against blank 3 . Erythrocyte CAT activity is linear up to $100 \mathrm{kU} / \mathrm{L}$. If the CAT activity exceeded $100 \mathrm{kU} / \mathrm{L}$ the serum was diluted with the phosphate buffer (two to 10 fold) and the assay was repeated. One unit CAT decomposes $1 \mathrm{mmol}$ of $\mathrm{H}_{2} \mathrm{O}_{2} / \mathrm{L}$ min under these conditions.

CAT $(\mathrm{kU} / \mathrm{gHb})=\frac{\mathrm{A}(\text { sample })-\mathrm{A}(\text { blank } 1)}{\mathrm{A}(\text { blank } 2)-\mathrm{A}(\text { blank } 3)} \times 271$

Blank 1 contained $1.0 \mathrm{ml}$ substrate, $1.0 \mathrm{ml}$ molybdate and $0.2 \mathrm{ml}$ hemolysate: blank 2 contained $1.0 \mathrm{ml}$ substrate, $1.0 \mathrm{ml}$ molybdate and $0.2 \mathrm{ml}$ buffer: blank 3 contained $1.0 \mathrm{ml}$ buffer, $1.0 \mathrm{ml}$ molybdate and $0.2 \mathrm{ml}$ buffer.

\section{DETERMINATION OF ERYTHROCYTE MALONDIALDEHYDE LEVELS}

Erythrocyte membrane MDA levels were measured in terms of thiobarbituric acid (TBA) reactive substances. MDA, an end product of fatty acid peroxidation, can react with TBA to form a colored complex that has a maximum absorbance at $532 \mathrm{~nm}$ (Jain et al., 1990).

\section{STATISTIC}

The mean values obtained in the different groups were compared by Student's $t$ test. Pearson's correlation test was used to evaluate the relationship between the two variables. All statistical analyses were performed with the program Statistical Package for the Social Sciences (SPSS) for Windows, version 7.5. All results were expressed as mean values $\pm \mathrm{SE}$; significance was defined as $\mathrm{p}<0.05$.

\section{RESULTS AND DISCUSSION}

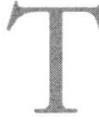

The CL patients and matched controls had similar ranges in terms of age, height, body weight, and body mass index (BMI) (Table I). Onset of

\begin{tabular}{lccl}
\hline & $\begin{array}{c}\text { Patients } \\
\mathbf{n}=\mathbf{3 2} \\
\text { Mean } \pm \text { SD }\end{array}$ & $\begin{array}{c}\text { Healthy Subjects } \\
\mathbf{n}=\mathbf{3 0} \\
\text { Mean } \pm \text { SD }\end{array}$ & $\boldsymbol{p}$ \\
\hline Sex $(\mathrm{F} / \mathrm{M})$ & $19 / 13$ & $17 / 13$ & \\
Age $($ year $)$ & $28.2 \pm 4.3$ & $27.3 \pm 4.5$ & $>0.05$ \\
Height $(\mathrm{cm})$ & $169 \pm 6$ & $167 \pm 5$ & $>0.05$ \\
Weight $(\mathrm{kg})$ & $64.1 \pm 8.9$ & $65 \pm 12.4$ & $>0.05$ \\
BMI $\left(\mathrm{kg} / \mathrm{m}^{2}\right)$ & $23.4 \pm 3.6$ & $24.7 \pm 4.4$ & $>0.05$ \\
\hline
\end{tabular}

Table I.- Physical characteristics of CL patients and healthy subjects. lesions was 3,4 \pm 1.2 months. As seen in the table II, erythrocyte MDA levels and erythrocyte SOD activities were significantly higher in the patient group than in healthy subjects ( $\mathrm{p}<0.01$ and $\mathrm{p}<0.01$, respectively). However, GSH-Px and CAT activities were found to be significantly lower in the patient group than in the controls ( $\mathrm{p}<0.01$ and $\mathrm{p}<0.05$, respectively). There was a tendency to decreased Hb levels (Fig. 1) and erythrocyte counts in patients group, however values did not reach statistical significance ( $p>0.05)$. There was a weak inverse relationship between erythrocyte MDA levels and $\mathrm{Hb}$ content in the erythrocytes of CL patients $(r=-0.389, p<0.05)$. However, erythrocyte MDA levels did not correlate with any of the antioxidant enzyme levels.

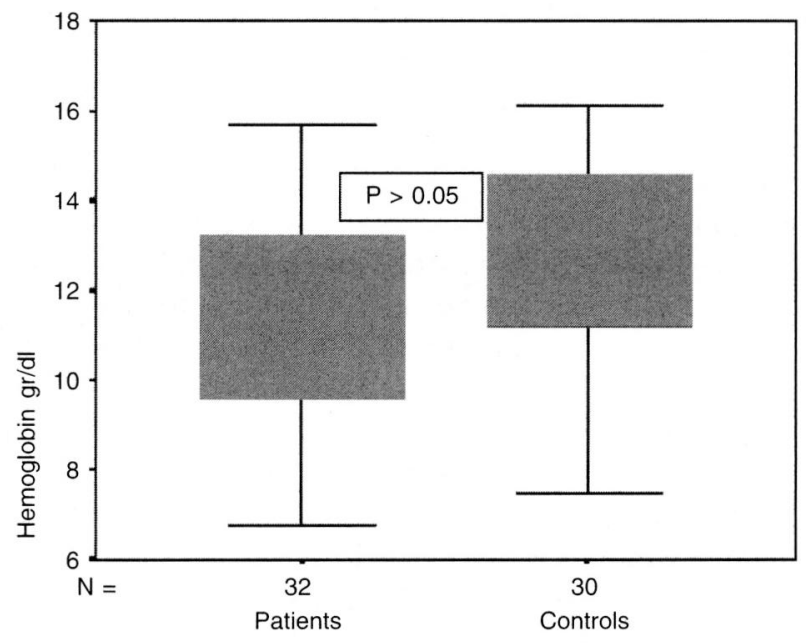

Fig. 1. - Blood hemoglobin ( $\mathrm{Hb})$ levels of patient and control groups $($ mean \pm SD).

Although CL is a local infection, the host generates some systemic immune defense mechanism(s) against $\mathrm{CL}$ infection. It has been demonstrated that immune mediators such as interferon-gamma (IFN- $\gamma$ ) and tumor necrosis factor-alpha (TNF- $\alpha$ ) produced by the host against Leishmania infection, regulate the metabolisms of nitric oxide (NO) and ROIs (Liew et al., 1990; Liew \& O'Donnel, 1993). Owing to the fact that the effects of cytokines in the circulation are systemic, other cells are likely to be affected. Erythrocytes abundantly contain SOD, CAT and GSH-Px enzymes and they reflect alterations in the activities of these enzymes well: The erythrocyte membrane is also sensitive to lipid peroxidation because it contains unsaturated fatty acids(Van Asbeck et al., 1985). Therefore, we measured the changes of these antioxidant enzyme activities, $\mathrm{Hb}$ levels and erythroyte counts, and the levels of lipid peroxidation in erythrocytes to evaluate ROIs and oxidative damage in patients with CL.

Previous studies have demonstrated that ROI can kill intracellular and extracellular Leishmania parasite (Ham- 


\begin{tabular}{lccc}
\hline \multicolumn{1}{c}{ Parameters } & $\begin{array}{c}\text { Patient Group } \\
\mathbf{n = 3 2}\end{array}$ & $\begin{array}{c}\text { Control Group } \\
\mathbf{n}=\mathbf{3 0}\end{array}$ & $\boldsymbol{p}^{\boldsymbol{a}}$ \\
\hline Erythrocyte pellet MDA, nmol MDA/Hb & $8.68 \pm 1.44$ & $4.16 \pm 1.161$ & $<0.01$ \\
Erythrocyte SOD, U/g Hb & $570.9 \pm 23.76$ & $425.4 \pm 24.26$ & $<0.01$ \\
Erythrocyte GSH-Px, U/g Hb & $31.58 \pm 3.60$ & $49.2 \pm 4.74$ & $<0.01$ \\
Erythrocyte CAT, kU/gHb & $115.70 \pm 10.22$ & $143.22 \pm 9.97$ & $<0.05$ \\
Hemoglobin g/dL & $11.32 \pm 2.70$ & $12.98 \pm 2.57$ & $>0.05$ \\
Erythrocyte $\left(\times 10^{6}\right)$ & $3.48 \pm 0.35$ & $3.97 \pm 0.34$ & $>0.05$ \\
\hline
\end{tabular}

Values are given Mean \pm SD

Table II. - Comparative analysis of lipid peroxidation of - as assessed by MDA content - and the monitoring of three anti-oxidant enzymes in erythrocytes recovered from either healthy subjects or patients with active cutaneous leishmaniasis.

moda et al, 1996; Clark et al, 1986). Specially $\mathrm{H}_{2} \mathrm{O}_{2}$, which is a product of the macrophage respiratory burst, is the major killing mechanism of microorganisms ( $\mathrm{Li}$ et al., 1992). An antioxidant enzyme, SOD, converts superoxide radicals into $\mathrm{H}_{2} \mathrm{O}_{2}$. On the other hand, CAT and GSH-Px convert $\mathrm{H}_{2} \mathrm{O}_{2}$ into $\mathrm{H}_{2} \mathrm{O}$ and $\mathrm{O}_{2}$. GSH-Px also plays a role in the detoxification of intracellular hydroperoxides. Therefore, increased SOD activity results in increased conversion of the superoxide anion into $\mathrm{H}_{2} \mathrm{O}_{2}$. At the same time, decrease in GSH-Px and CAT activities decrease the degradation of $\mathrm{H}_{2} \mathrm{O}_{2}$, so that it remains in the medium for a long time at a high concentration in their in vitro study (Rockett et al., 1991). Studies have also demonstrated that SOD can effectively enhance vascular relaxation and the half-life of NO (Gryglewski et al., 1986; Assreuy et al., 1994). On the contrary, it was reported that CAT inhibits macrophage leishmanicidal activity and this correlates with a reduction in NO synthesis (Li et al., 1992). Therefore, increased SOD activity, and decreased CAT and GSH-Px activities may cause to the elevated production of $\mathrm{NO}$ and $\mathrm{H}_{2} \mathrm{O}_{2}$ via two independent pathways to kill parasite. Anyway, it was demonstrated that the addition of SOD to macrophages enhanced leishmanicidal activity (Assreuy et al., 1994).

The differences of antioxidant enzyme activities in the CL patient may be a defense strategy of the organism induced by cytokines, such as IL-1, IL- 2 and TNF- $\alpha$. It was demonstrated that SOD activity was significantly induced by IL- 1 and TNF- $\alpha$ (Rubany \& Vanhoutte, 1986), and GSH-Px activity induced by IL-2r (Reimund et al., 2000). Although, we could not determine these immunocytokins, some in vivo and in vitro observations shown that the production of IL- 1 and TNF- $\alpha$ were also induced by CL infection (Pirmez et al., 1993; Cillarie et al., 1989).

Contrary to our findings, SOD activity has been found to be decreased along with GSH-Px and CAT activities in Leishmania donovani infection (Biswas et al., 1997). This difference in findings between visceral and CL may be due to a distinct pathology and immune response in these two species of Leishmania, as IL-1 has also been found to be lower in Leishmania donovani infection in contrast to CL infection (Reiner, 1987).

Stimulation of lipid peroxidation of red cell membrane was evident from the increased levels of MDA in the erythrocytes of CL patients. Because, the production of ROIs to kill microorganism may also cause oxidative damage in the other cells or tissues such as erythrocytes at the same time. Likewise we found to be a higher erythrocyte membrane MDA levels and a weak inverse correlation between and $\mathrm{Hb}$ and erythrocyte MDA content. Biswas et al. (1997) also indicated that there was a severe peroxidative injury in the erythrocytes and an anemia of indian kala-azar patients, but Leishmania donovani infection is a generalized systemic infection than CL infection. To our knowledge, this is the first report indicating peroxidative injury in the erythrocytes of CL patients.

\section{CONCLUSION}

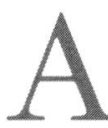
lthough CL is a local parasitic infection, some systemic antioxidative enzyme activities change probably as a part of the host defense. However, oxidant/antioxidant balance may be tilted towards the oxidative side, with the end result being uncontrolled peroxidative damage.

\section{REFERENCES}

Assreuy J., Cunha F.Q., Epperlein M., Noronha-Dutra A., O'Donnell CA., LIEW F.Y. \& MONCADA S. Production of nitric oxide and superoxide by activated macrophages and killing of Leishmania major. European Journal of Immunology, 1994, 24, 672-676.

Biswas T., Ghosh D.K., Mukherjee N. \& Ghosal J. Lipid peroxidation of erythrocytes in visceral leishmaniasis. Journal of Parasitology, 1997, 83, 151-152.

Clark I.A., Hunt H.N. \& Cowden W.B. Oxygen-derived free 
radicals in the pathogenesis of parasitic disease. Advances in Parasitology, 1986, 25, 1-44.

Cillarie E., Dieli M., Maltase E., Milano S., Salerno A. \& liew F.Y. Enhancement of macrophage IL-1 production by Leishmania major infection in vitro and its inhibition by IFN-g. Journal of Immunology, 1989, 143, 2001-2005.

Erel O, Kocyigit A, Bulut V. \& Gurel M.S. Reactive nitrogen and oxygen intermediates in patients with cutaneous leishmaniasis. Memórias do Instuto Oswaldo Cruz, 1999, 94, 179-183.

Goth L. A simple method for determination of serum catalase activity and revision of reference range. Clinical Chim Acta, 1991, 196, 43-52.

Gramiccia M, Bettini S. \& Yasarol S. Izoenzyme characterization of leishmania isolates from human cases of cutaneous lesihmaniasis in Urfa, south-east Turkey. Transactions of the Royal Society of Tropical Medicine and Hygiene, 1984, 78, 568-569.

Gryglewski R.J., Palmer R.M. \& Moncada S. Superoxide anion is involved in the breakdown of endothelium-derived vascular relaxing factor. Nature, 1986, 320, 454-456.

Gurel M.S., Ulukanligil M. \& Ozbilge H. Cutaneous leishmaniasis in Sanliurfa: Epidemiological and clinical features of the four years (1997-2000). International Journal of Dermatology, 2002, 41, 32-37.

Hammoda N.A., Negm A.Y., Hussein E.D., EL-Temsahy M.M. \& RASHWAN E.A. Leishmania major: leishmanicidal activity of activated macrophages by interferon gamma and tumor necrosis factor alpha. Journal of Egyptian Society of Parasitology, 1996, 26, 555-566.

Jain S.K., Levine S.N., Duett J. \& Holdier B. Elevated lipid peroxidation levels in red blood cells of streptozotocintreated diabetic rats. Metabolism, 1990, 39, 971-975.

li Y., Severn A., Rogers M.V., Palmer R.M., Moncada S. \& Liew F.Y. Catalase inhibits nitric oxide synthesis and the killing of intracellular Leishmania major in murine macrophages. European Journal of Immunology, 1992, 22, 441-446.

Liew F.Y., Parkinson C., Millor S., Severn A. \& Carrier M. Tumor necrosis factor (TNF-a) in leishmaniasis 1.TNF-a mediates host protection against cutaneous leishmaniasis. Immunology, 1990, 69, 570-573.

Liew F.Y. \& O'DONNel C.A. Immunology of leishmaniasis. Advances in Parasitology, 1993, 32, 162-222.

McCord J.M. \& Fridovich I. Superoxide dismutase. An enzymatic function for erythrocuprein (hemocuprein). Journal of Biological Chemistry, 1969, 244, 6049-6055.

McCord J.M. Human disease, free radicals, and the oxidant/antioxidant balance. Clinical Biochemistry, 1993, 26, 351-357.

Paglia D.E. \& Valentine W.N. Studies on the quantitative and qualitative characterization of erythrocyte glutathione peroxidase. Journal of Laboratory Clinical Medicine, 1967, 70, 158-169.

Pirmez C., Yamamura M., Uyemura K., Paes-Oliveira M., Conceicao-Silva F. \& Modlin R.L. Cytokine patterns in the pathogenesis of human leishmaniasis. Journal of Clinical Investigations, 1993, 91, 1390-1395.
Raziuddin S., AbDalla R.E., El-Awad E.H. \& Al-Janadi M. Immunoregulatory and proinflammatory cytokine production in visceral and cutaneous leishmaniasis. Journal of Infectious Diseases, 1994, 170, 1037-1040.

Reimund J.M., Hirth C., Koehl C., Baumman R. \& Duclos B. Antioxidant and immune status in active Crohn's disease. A possible relationship. Clinical Nutritien, 2000, 19, 4348.

ReIner N.E. Parasite accessory cell interactions in murine leishmaniasis. I. Evasion and stimulus-dependent suppression of the macrophage interleukin 1 response by Leishmania donovani. Journal of Immunology, 1987, 138, 1919-1925.

Rockett K.A., Awburn M.M., Cowden W.B. \& Clark I.A. Killing of Plasmodium falciparum in vitro by nitric oxide derivatives. Infect Immun, 1991, 59, 3280-3283.

Rubany G.M. \& Vanhoutte P.M. Oxygen-derived free radicals, endothelium, and responsiveness of vascular smooth muscle. American Journal of Physiology, 1986, 250, 815821.

Van Asbeck B.S., Hoidal J., Vercellotti G.M., Schwartz B.A., Moldow C.F. \& ACOB H.S. Protection against lethal hyperoxia by tracheal insufflation of erythrocytes: role of red cell glutathione. Science, 1985, 227, 756-759.

Von Kompen E.J. \& ZiljLSTRA W.G. Standardization of hemoglobinometry. II. The hemoglobincyanide method. Clinical Chim Acta, 1961, 6, 538-544.

Reçu le 22 octobre 2002 Accepté le 9 mai 2003 